\title{
The Role of Family Support in the Recovery of Corona Virus Disease-19 Patients
}

\author{
Diadjeng Setya Wardani ${ }^{1 *}$, Syamsul Arifin ${ }^{2}$ \\ ${ }^{1}$ Department of Midwifery, Faculty of Medicine, Brawijaya University, Malang, Indonesia; ${ }^{2}$ Department of Administration and \\ Health Policy, Faculty of Medicine, Lambung Mangkurat University, Banjarmasin, Indonesia
}

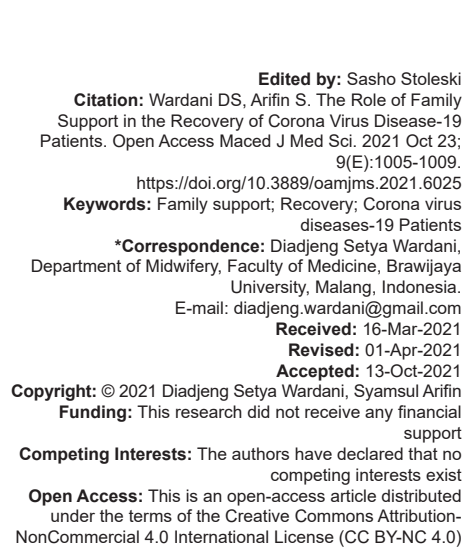

\section{Introduction}

The number of people in Indonesia infected with the Coronavirus diseases (COVID-19) is increasing every day, bringing concern to all elements of society. Positive confirmed cases of corona as of today (February 2021) have reached 1.1 million people. However, on the other hand, the cure rate for COVID-19 patients is also reported to continue to increase, reaching 897 thousand people. As for the death toll confirmed positive for the corona virus, it was 30,581 people. The outbreak of the corona virus that never ends has affected many sectors, from the economic, social, education, to health sectors. The emergence of the bad effects of the spread of the corona virus certainly makes the public uneasy; this is because the corona virus can cause casualties [1].

The emergence of bad effects from the spread of the corona virus can certainly disturb everyone's psychology, such as panic buying, stress, and anxiety. Even though the government has implemented a physical distancing policy that aims to break the chain of spreading this virus, there are still many people who do not heed these rules. There are still many people who are still congregating in public places, there are still many stalls in traditional markets within close proximity, and many people carry out work activities without heeding appeals from the government. This of course makes breaking the chain of the spread of the corona virus difficult.

Breaking the chain of the spread of COVID-19 can be done by preventing and handling COVID-19 in the smallest aspect, namely family. Families have an important role in prevention, especially for patients who are positive for COVID-19 with mild symptoms and without symptoms to recover. Support such as providing positive information about the COVID-19 virus, moral reinforcement and special time given by the family is thought to strengthen mentally and can increase the immunity of the exposed patient. With this support can still have positive thoughts to increase their immunity [2].

Family support according to Francis and Satiadarma, 2004 [3] is assistance/support received by one family member from other family members to carry out the functions contained in a family. The success of hospital treatment, namely the provision of drugs, will be useless if it is not supported by family support. Research shows that family caregivers are a very 
potential source to support psychological recovery in the patients. Jennifer, 2020 [4] states that family plays an important role in determining the methods or care needed by patients at home, so that it will reduce the recurrence rate. The results of this study are confirmed by research by Dalami, 2010 [5], which states that the family has a strategic function in reducing the recurrence rate of disease, increasing independence and living standards, and the patients can adapt again to society and their social life.

The above opinion is also strengthened, that family support can strengthen each individual, create familystrength, increase self-esteemorself-assessment, has the potential as the main prevention strategy for all families in facing the challenges of everyday life and has relevance in a society that is in a stressful environment. Family support that is owned by someone can prevent the development of problems due to the pressure they are facing. Someone with high support will be more successful in dealing with and overcoming the problem than someone who does not have support. Therefore, this study was conducted with the aim of knowing the role of family support for the recovery of COVID-19 patients.

\section{Methods}

This research is a quantitative study using an analytic observational approach. The subjects of this study were 30 family members who have families suffering from COVID-19 and live in one house and 30 patients who recovered from COVID-19 spread across the islands of Java and Kalimantan. The research method used was observational analytic with a crosssectional approach. Data analysis used Fisher's exact test and calculated the prevalence ratio to determine the most dominant family support affecting the recovery of COVID-19 patients.

\section{Results}

Table 1 shows that the most family members who have recovered from COVID-19 are 21 to 30 years old, namely $43.33 \%$ years, while most of the patients who recovered Covid-19 (40\%) were aged 31-40 years. The last education category, for the patient's family, showed that the majority $(76.67 \%)$ had a diploma and bachelor degree, while for patients who recovered from COVID-19; it also showed that most (63.33\%) had a diploma and bachelor degree.

For the occupational category, most of both families and patients are mostly civil
Table 1: Frequency distribution of family characteristics and patients cured of COVID-19

\begin{tabular}{|c|c|c|c|c|}
\hline \multirow[t]{2}{*}{ Characteristic of respondents } & \multicolumn{2}{|c|}{ The patient's family } & \multicolumn{2}{|c|}{$\begin{array}{l}\text { The patient recovered } \\
\text { from COVID-19 }\end{array}$} \\
\hline & $\mathrm{n}$ & $\%$ & $\mathrm{n}$ & $\%$ \\
\hline \multicolumn{5}{|l|}{ Age } \\
\hline $21-30$ years & 13 & 43.33 & 11 & 36.67 \\
\hline $31-40$ years & 12 & 40 & 12 & 40 \\
\hline $41-50$ years & 3 & 10 & 1 & 3.33 \\
\hline$>50$ years & 2 & 6.67 & 6 & 20 \\
\hline Total & 30 & 100 & 30 & 100 \\
\hline \multicolumn{5}{|l|}{ Last education } \\
\hline Senior high school & 2 & 6.67 & 5 & 16.67 \\
\hline Diploma and bachelor degree & 23 & 76.67 & 19 & 63.33 \\
\hline Master degree & 4 & 13.33 & 6 & 20 \\
\hline Total & 30 & 100 & 30 & 100 \\
\hline \multicolumn{5}{|l|}{ Profession } \\
\hline Civil cervant/police/military & 14 & 46.67 & 11 & 36.67 \\
\hline Employees of state owned corporation & 2 & 6.67 & 3 & 10 \\
\hline Private job & 5 & 16.67 & 4 & 13.33 \\
\hline Entrepreneur & 5 & 16.67 & 8 & 26.67 \\
\hline Unemployed & 3 & 10 & 4 & 13.33 \\
\hline Total & 30 & 100 & 30 & 100 \\
\hline \multicolumn{5}{|l|}{ Income (IDR) } \\
\hline$<1$ million & 4 & 13.33 & 2 & 6.67 \\
\hline 1-2 million & 1 & 3.33 & 7 & 23.33 \\
\hline 2-5 million & 16 & 53.33 & 10 & 33.33 \\
\hline$>5$ million & 8 & 26.67 & 11 & 36.67 \\
\hline Total & 30 & 100 & 30 & 100 \\
\hline
\end{tabular}

servants/military/police, with $46.67 \%$ and $36.67 \%$, respectively. The last category is income, indicating that the patient's family income, mostly $(53.33 \%)$ 2-5 million and for patients cured of COVID-19, and $36.67 \%$ income $>5$ million.

Based on Table 2, it shows that the support provided by families to COVID-19 patients, which consists of emotional support, shows good results $(76.7 \%)$, appreciation support or good judgment (90\%), good informational support (83.3\%), and good instrumental support (80\%).

Table 2: Family support for COVID-19 patient recovery

\begin{tabular}{|c|c|c|c|c|c|}
\hline \multirow[t]{2}{*}{ Parameter } & \multicolumn{2}{|c|}{ Good support } & \multicolumn{2}{|c|}{ Bad support } & \multirow[t]{2}{*}{ Total (\%) } \\
\hline & $\mathrm{n}$ & $\%$ & $\mathrm{n}$ & $\%$ & \\
\hline Family support & 25 & 83.3 & 5 & 16.67 & $30(100)$ \\
\hline Emotional support & 23 & 76.7 & 7 & 23.3 & $30(100)$ \\
\hline Appreciation or appraisal support & 27 & 90 & 3 & 10 & $30(100)$ \\
\hline Informational support & 25 & 83.3 & 5 & 16.67 & $30(100)$ \\
\hline Instrumental support & 24 & 80 & 6 & 20 & $30(100)$ \\
\hline
\end{tabular}

Based on Table 3, it shows that all indicators of family support consisting of emotional support, reward or assessment support, informational support, and instrumental support have an effect on the recovery of COVID-19 patients $(<0.05)$. From the calculation of the prevalence ratio, it shows that the support that has the most significant effect on the recovery of COVID-19 patients is emotional support $(P R=0.714)$, instrumental support $(P R=0.667)$, informational support $(P R=0.600)$, and reward support or assessment $(P R$ $=0.333$ ). 
Table 3: The role of family support in the recovery of COVID-19 patients

\begin{tabular}{lll}
\hline Influence between variables & $\mathrm{p}$-value exact Sig..(2-sided) & Prevalence ratio \\
\hline Family support $\Rightarrow$ Recovery & 0.023 & 0.600 \\
Emotional support $\Rightarrow$ Recovery & 0.048 & 0.714 \\
Appreciation or appraisal support $\Rightarrow$ & 0.007 & 0.333 \\
Recovery & & \\
Informational support $\Rightarrow$ Recovery & 0.023 & 0.600 \\
Instrumental support $\Rightarrow$ Recovery & 0.034 & 0.667 \\
\hline
\end{tabular}

\section{Discussion}

Family support is a form of interpersonal relationship that protects a person from the effects of bad stress, or a form of interpersonal relationship that includes attitudes, actions and acceptance of family members, so that family members feel someone is paying attention [6]. Family social support is a process that occurs throughout life, the nature and types of social support vary in different stages of the life cycle. However, in all stages of the life cycle, family social support enables the family to function with a variety of intelligences and minds. As a consequence, it improves family health and adaptation [7] (Friedman, 2010).

Friedman, 2010 concluded that both buffer effects (social support with stand the negative effects of stress on health) and main effects (social support directly affects the consequences of health) are found. In fact the buffering and primary effects of social support on health and well-being may function simultaneously [7].

Based on the combined calculation of all indicators, family support is proven to have a significant role in the recovery of COVID-19 patients with $p=0.023$. The results of this significance are supported by field data which shows factually dominant family support from both recovered COVID-19 patients.

\section{Emotional support}

The results of the study based on the recapitulation of answers from the patient's family found that the emotional support provided by the family generally showed good support; from 30 respondents, it showed that the majority of COVID-19 patients, in this study, were known to be good at getting emotional support by $76.7 \%$. Based on statistical analysis, it is known that there is an effect of informational support on the recovery of COVID-19 patients $(p=0.048)$.

Middle east respiratory syndrome-corona virus (MERS-CoV) or commonly abbreviated as MERS-CoV is a respiratory syndrome disease caused by a coronavirus that attacks the respiratory tract from mild to severe. This disease is caused by infection with the corona virus, a virus that is related to the virus that causes SARS. The MERS-CoV virus is a new strain of corona virus that has never been found to infect humans before [8].

So deadly is this virus that it causes people who have been diagnosed with the disease or have family members diagnosed with COVID-19 to feel fear and anxiety. Education and family assistance in the recovery process of this disease are very important. COVID-19 patients who receive support from their family and closest relatives will greatly influence their recovery, because it can generate positive hormones for these patients [9]. The recovery of Covid-19 patients is not only due to medical factors such as taking drugs. Psychological factors such as support from family and closest people also have a positive impact on the recovery of corona patients [10].

The family provides a safe and peaceful place for rest and recovery and aids in controlling emotions. The family provides expressions of love, care, appreciation, and sympathy, and creates a sense of trust, listens and is heard. Emotional support in the form of expressions of affection, empathy and respect is very much needed by COVID-19 patients. Aspects of emotional support include the form of family assistance, the form of attention given by the family, the efforts made to arouse the patient's enthusiasm, and the form of fulfilling the needs provided by the family in curing COVID-19 patients.

Emotional support includes expressions of empathy, care and concern for the person concerned. This form of support makes family members who are sick feel comfortable, feel confident that they are needed and loved by social support sources, so that they can deal with problems better. The family provides a safe and peaceful place for rest and recovery and helps with emotional control.

Aspects of emotional support include support in the form of affection, trust, attention, listening, and being heard. According to Julianto, emotional support consists of verbal and non-verbal information or advice, real help or actions provided by social intimacy. For example, family members who experience a deadly disease such as COVID-19 can pour out all their feelings to the family, in this case the family is obliged to provide comfort, a sense of peace in the hearts of family members who experience pain and increase self-confidence in themselves. The family is a safe and peaceful place for family members to rest and recover as well as help control emotions [6].

\section{Appreciation or appraisal support}

The appreciation or appraisal support provided by the family generally shows good support. Based on the results of the study, it shows that the majority of COVID-19 patients in this study are known to be good at getting support for awards or assessments from their families, which is $90 \%$. Based on statistical analysis, it is known that there is an influence between reward support and an assessment of the recovery of COVID-19 patients $(p=0.007)$

The results of this study are in line with research conducted by Saputra, 2010 [11] which states that assessment support is related to the prevention of 
relapse. Assessment support occurs through positive expressions of respect (appreciation), encouragement or approval of an individual's ideas or feelings, and positive comparisons of that person with others, for example by comparing him with others who are in worse condition. The family acts as a feedback guide, guides and mediates problem solving, as a source and validator for the identity of family members, including providing support, appreciation, and attention [12].

Support of appreciation, family acting (the family acts as a feedback guiding system, guiding and chaining problem solving and is a source of validator for the identity of members [7]. Award support occurs through positive expressions of appreciation involving statements of agreement and positive assessment of ideas, feelings and performance of others are positively proportional between individuals and others [13].

Based on the results of the study, the researchers concluded that the function of reward or assessment of the family is very important to increase enthusiasm, motivation and increase self-esteem for family members who suffer from COVID-19. This can affect the formation of adaptive behavior in an effort to improve their health. In addition, it can also make the patient's life more valuable and meaningful to his family because he feels that he is still needed by other people, especially his family.

\section{Informational support}

Informational support for this research is well known. The patients in getting good informational support were $83.3 \%$. Based on the results of statistical analysis, it is known that there is an effect of informational support on the recovery of COVID-19 patients $(p=0.023)$. This is in accordance with the theory which states that the support of information in the family, namely by providing information to family members who are sick, can provide peace and mental readiness in themselves in dealing with their illness.

This support is carried out by families who always try to provide explanations about things that can accelerate the recovery of the condition of patients who are suffering from COVID-19 so that an optimistic attitude and always positive thoughts are very important factors to accelerate recovery. Families must always be ready when a sick family member asks anything related to the treatment procedures for COVID-19 sufferers, therefore the family must always update their knowledge.

Informational support is family support that functions as a collector and disseminator (spreader) of information about the world. Information support occurs and is provided by the family in the form of advice, suggestions and discussions on how to solve or solve existing problems [14]. Informational support is support where the family functions as a collector and disseminator, namely the disseminator of information.
When a family member is diagnosed positive for COVID-19 and needs help, the family starts looking for information related to health problems that are being experienced by family members.

Information obtained by families and patients can be obtained through consultations with professionals, reading sources, or asking other supportive sources to increase hope and confidence in efforts to achieve the recovery of their families. Informational support includes providing advice, hints, suggestions, or feedback. This type of information can help individuals to identify and solve problems more easily [5], [15]. Based on the research conducted, the researcher argues that the results of the study are in accordance with related theories and several previous studies, that the informational support that families provide to patients will play an important role in the recovery of COVID-19 patients.

\section{Instrumental support}

Instrumental support in a study of 32 respondents who showed that COVID-19 patients were known to be good at getting instrumental support (80\%). Based on the results of statistical analysis, it is known that there is an effect of instrumental support on the recovery of COVID-19 patients $(p=0.034)$. Instrumental support includes direct assistance. This form of support can reduce individual burdens because individuals can directly solve problems related to the material.

Family is a source of practical and real help, including the patient's health in terms of the need for food and drink, rest, avoidance of sufferers from sufferers. Instrumental support is support where the family is expected to be able to facilitate all the needs of family members who are experiencing illness, both biopsychosocial and spiritual needs. Biological needs are basic needs and needs that must be met by families [7].

Instrumental support, the family is a source of practical and concrete help [7]. Instrumental support is support provided by the family directly which includes materials such as providing shelter, lending or providing money and assistance in daily life [14]. In this study, the instrumental support provided by family members to patients is in the form of special facilities for COVID-19 patients (comfortable, quiet, adequate independent isolation room), providing material assistance for test and treatment costs, and material assistance for patient members affected by COVID-19 [16], [17].

The results of this study indicate that instrumental support is not only a biological need, but also a psychological need such as providing a comfortable place to family members so that the illness experienced indirectly can be felt a little lighter. In addition, social needs that come from outside the environment such as the community and spiritual needs 
which are the need to worship and get closer to God must also be fulfilled by the family.

\section{Conclusions}

Family support has a significant role in the recovery of COVID-19 patients spread across the islands of Java and Kalimantan, with a $p=0.023$ with each indicator being emotional support (0.048), reward support or assessment (0.007), informational support (0.023), and instrumental support (0.034). The indicator of family support that has the greatest contribution to recovery is the emotional indicator (PR 0.714).

It is hoped that the results of this study can become the basis for further research on patients recovering COVID-19 and for further researchers to develop this study with a larger number of patients and families.

\section{References}

1. Chew NW, Lee GK, Tan BY, Jing M, Goh Y, Ngiam NJ, et al. A multinational, multicentre study on the psychological outcomes and associated physical symptoms amongst healthcare workers during COVID19 outbreak. Brain Behav Immun. 2020;88:559-65. https://doi.org/10.1016/j.bbi.2020.04.049

PMid:32330593

2. COVID-19 Handling Task Force. COVID-19 Data, Jakarta; 2020. Available from: https://www.covid19.go.id/scatter-map

3. Francis S, Satiadarma MP. The effect of family support on the recovery of mothers with breast cancer. J Sci Psychol. 2004;9(1):1-5.

4. Jennifer M. Characteristics of and important lessons from the Coronavirus disease 2019 (COVID-19) outbreak in China summary of a report of 72314 cases from the chinese center for disease control and prevention. JAMA New Open. 2020;9(E):E1-4. https://doi.org/10.1001/jama.2020.2648

5. Dalami E. Basic Concepts of Mental Health Nursing. Trans Info
Media East Jakarta. 2010:9(E).

6. Fahanani FG. Relationship of Knowledge About Mental Disorders With Family Support Having Schizophrenic Family Members at RSJD Surakarta;2010. https://doi.org/10.26576/ profesi.147

7. Friedman MM, Bowden VR, Jones EG. Textbook of Family Nursing: Research, Theory and Practice. Jakarta: EGC; 2010. p. 5-6. https://doi.org/10.31237/osf.io/s7avu

8. Bhagavathula AS, Aldhaleei WA, Rahmani J, Ain A, Dhabi A Knowledge and perceptions of COVID-19 among health care workers: Cross-sectional study. JMIR Public Health Surveill. 2020;6(2):e19160. https://doi.org/10.2196/19160 PMid:32320381

9. Fadli SM, Mitra M. Knowledge and emotional expression of family and frequency of relapse of schizophrenic patients. Nat Public Health J. 2013;7(10):466-70. https://doi.org/10.21109/ kesmas.v7i10.6

10. Dolan P, Canavan J, Pinkerton J. Family Support as Reflective Practice. London:Jessica Kingsley Publishers;2006.

11. Saputra N. Relationship between Family Support and Recurrence of Schizophrenia Patients at the Regional Mental Hospital Polyclinic of North Sumatra Province-Medan. Outpatient Support Hub with Recurrence of Ski Patients Polyclinic Mental Hospital Drh North Sumatra-Medan Province;2010. https://doi. org/10.31258/jni.8.2.203-214

12. Simanjuntak J. Building Family Mental Health and Children's Future. Gramedia Main Library; 2013.

13. Shanafelt T, Ripp J, Trockel M. Understanding and addressing sources of anxiety among health care professionals during the COVID-19 pandemic. JAMA. 2020;323(21):2133-4. https://doi. org/10.1001/jama.2020.5893

PMid:32259193

14. Pangastiti NK, Rahardjo M. Analysis of the Effect of Family Social Support on Burnout in Health Nurses in Mental Hospitals (Study at Prof. Dr. Soerojo Hospital Magelang);2011. https://doi. org/10.36086/jpp.v14i1.399

15. Nuraenah N, Mustikasari M, Putri YS. Relationship between family support and family burden in caring for members with history of violent behavior at Rs. The Islamic Spirit of Klender Jakarta Timur 2012. J Ment Nurs. 2014;2(1):41-50. https://doi. org/10.32584/jikk.v1i2.176

16. World Health Organization. Coronavirus disease 2019 (COVID-19) Situation Report-51. Geneva: World Health Organization; 2020. Available from:https://www.who.int/ emergencies/diseases/novelcoronavirus-2019/situation-reports

17. World Health Organization. Coronavirus Disease 2019 (COVID-19).Geneva: World Health Organization; 2020. Available from:https://www.who.int/emergencies/diseases/ novel-coronavirus-2019

Author Query???

AQ4: Kindly provide last accessed details 